\title{
TO THE QUESTION OF THE DETERMINATION OF GEOMETRIC CHARACTERISTICS OF THE SECTION OF CORRUGATED BEAMS WITH TRAPEZOIDAL WEBS BASED ON THE SIMULATION RESULTS
}

\author{
Tatiana L. Dmitrieva, Khukhuudei Ulambayar
}

Irkutsk National Research Technical University, Irkutsk, RUSSIA

\begin{abstract}
An algorithm for calculating the geometric characteristics of steel I-beams with plate corrugated webs of arbitrary type is proposed. The algorithm is implemented using the I-beam with plate trapezoid webs as an example. The determination of reduced area and moments of inertia in the axes of the cross section of the trapezoidal profile based on the finite element modeling of the beam with shell elements in calculations for bending and axial compression in the "ANSYS 14.5" software package is described. The verification procedure has been performed for a shell finite element model using the example of an I-beam with a standard flat web. A table has been compiled of geometric characteristics of rod corrugated elements of a trapezoidal profile in order to realize their finite element calculation using a rod diagram. An example of the calculation of a flat frame with a horizontal corrugated element, made in software package "LIRA-SAPR" using a flat rod diagram is given.
\end{abstract}

Keywords: shell finite element, rod finite element, simulation results, numerical analysis, maximum deflection, moment of inertia, software "ANSYS"

\section{К ВОПРОСУ ОПРЕДЕЛЕНИЯ ГЕОМЕТРИЧЕСКИХ ХАРАКТЕРИСТИК СЕЧЕНИЯ ГОФРОБАЛОК С ТРАПЕЦЕИДАЛЬНЫМИ СТЕНКАМИ НА ОСНОВЕ КОМПЬЮТЕРНОГО МОДЕЛИРОВАНИЯ}

\author{
Т.Л. Дмитриева, Х.Уламбаяр \\ Иркутский национальный исследовательский технический университет, г. Иркутск, РОССИЯ
}

\begin{abstract}
Аннотация: Предложен алгоритм вычисления геометрических характеристик стальных двутавровых балок с пластинчатыми гофрированными стенками произвольного вида. Алгоритм реализован на примере балок с трапецеидальными стенками. Описано нахождение приведенной площади и моментов инерции в осях поперечного сечения трапецеидального профиля на основе конечно-элементного моделирования балки оболочечными элементами в расчетах на изгиб и осевое сжатие в программном комплексе "ANSYS 14.5". Выполнена процедура верификация оболочечной конечно-элементной модели на примере для двутавровой балки со стандартной прямой стенкой. Составлена таблица геометрических характеристик стержневых гофро-элементов трапецеидального профиля с тем, чтобы реализовать их конечно-элементный расчет по стержневой схеме. Приведен пример расчета плоской рамы с горизонтальным гофроэлементом, выполненный в ПК “ЛИРА-САПР” с применением плоской стержневой схемы.
\end{abstract}

Ключевые слова: компьютерное моделирование, численный анализ, оболочечный конечный элемент, стержневой конечный элемент, момент инерции, программный комплекс «ANSYS»

\section{INTRODUCTION}

I-beams with plate corrugated webs have not widely used in the design of buildings and structures until a certain time [1]. In the past decade, it has been recognized that cold-formed steel beams of various corrugation configurations can be effectively used as bearing components of the framework. 


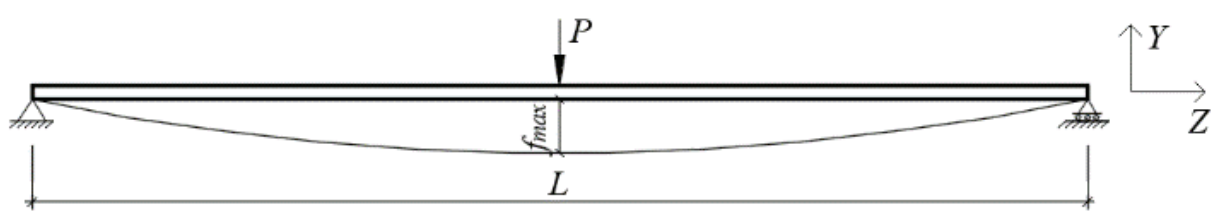

Figure 1. Calculation scheme.

The use of corrugated webs allows the use of thin plates without the need to install stiffeners, which contributes to reducing the weight and cost of the beam [2-4]. Economical expediency of corrugated elements is substantiated in [1, 58]. Same source notes main flaws in design of such constructions, which are mainly caused by lack of normative documents, literature and special computation software. The use of such structures is difficult the complexity to analyze their stress-strain state [9-14]. The standard scheme for calculating frameworks of buildings is based on a rod finite element model using geometric characteristics of the cross sections of rod elements. Meanwhile, tabulated values of the geometric characteristics are known for certain corrugation types - triangle [15] and wave types (SIN beams) [16]. For corrugations of an arbitrary profile there are no assortments containing bending, axial and other characteristics of section stiffness. This article proposes an algorithm for determining the geometric characteristics of corrugated beams using the example of beams with corrugated trapezoidal webs.

\section{CALCULATION SCHEME MODEL}

As an example, consider a single-span model (Figure 1).

The system of differential equations describing the displacement of the beam y (z) has the form given flexural shear

$$
\left\{\begin{array}{l}
\frac{d y(z)}{d z}=-\frac{M(z)}{E \cdot I} \\
\frac{d y}{d z}=y(z)+\frac{k \cdot P}{G \cdot A_{2 \mathrm{f}}}
\end{array},\right.
$$

Substituting from the second equation of system (1) into the first, we obtain the second order equation:

$$
\frac{d^{2} y}{d z^{2}}=-\frac{M(z)}{E \cdot I}+\frac{d}{d z} \cdot\left(\frac{k \cdot P}{G \cdot A_{2 f}}\right),
$$

where, $P$ is the applied load, $E$ and $G$ are modulus of elasticity and shear modulus, respectively, $I$ is the moment of inertia of the cross section, $k$ is a factor related to the cross section shape, $A_{2 \mathrm{f}}$ is the area of two flange, $M$ is the bending moment.

The solution of the differential equat. 2 taking into account the conditions for fixing the beam is as follows:

$$
y=\frac{P \cdot L^{2}}{16 \cdot E \cdot I} \cdot z-\frac{P}{12 \cdot E \cdot I} \cdot z^{3}+\frac{k \cdot P}{G \cdot A_{2 \mathrm{f}}} \cdot z,
$$

Then, at $z=L / 2$, we get at mid-span deflection with allowance for bending and shear deformations:

$$
y_{z=L / 2}=f_{\max }=\frac{P \cdot L^{3}}{48 \cdot E \cdot I}+\frac{k \cdot P \cdot L}{2 \cdot G \cdot A}
$$

From condition (4) we express the moment of inertia:

$$
I=\frac{P \cdot L}{48 \cdot E \cdot\left(f_{\max }-\frac{k \cdot P \cdot L}{4 \cdot G \cdot A_{\mathrm{f}}}\right)} .
$$

where, $A_{\mathrm{f}}$ is the area of one flange.

This addiction can be used in determining the geometric characteristics of the cross section of steel I-beams with corrugated webs. In this case, 
To the Question of the Determination of Geometric Characteristics of the Section of Corrugated Beams with Trapezoidal Webs Based on the Simulation Results

the maximum deflection $f_{\max }$ is determined by automatic calculation using certified software systems that use the spatial model of FE of steel I-beams with corrugated webs.

\section{ALGORITHM FOR DETERMINING GEOMETRIC CHARACTERISTICS OF THE CROSS-SECTION OF BEAMS WITH CORRUGATED WEBS OF ARBITRARY TYPE}

The algorithm for selecting geometric characteristics of a section for an I-beam with a corrugated web from an arbitrary profile includes the following steps:

- revealing of analytical dependences of displacements from the applied load through stiffness parameters of the beam;

- selection of rational dimensions of the cross sections of beams;

- selection of rational dimensions I-beams with trapezoidal webs;

- definition of deflections based on the finite element model of the shell when bending the beam;

- determination of axial displacement based on shell finite element model under axial compression;

- determination of geometric characteristics of sections of beams with corrugated webs and tabulation of results.

\subsection{Analytical dependences of displacements from the stiffness parameters of the beam.}

Consider a corrugated beam with trapezoidal webs when loaded with concentrated forces $P_{x}$ and $P_{y}$ in the middle of a span in two planes (Figure 2, Figure 3).

Based on the expression (5), we write down the relations for moments of inertia of cross sections of the beam in two planes.

a. Moment of inertia $I_{x}$ :

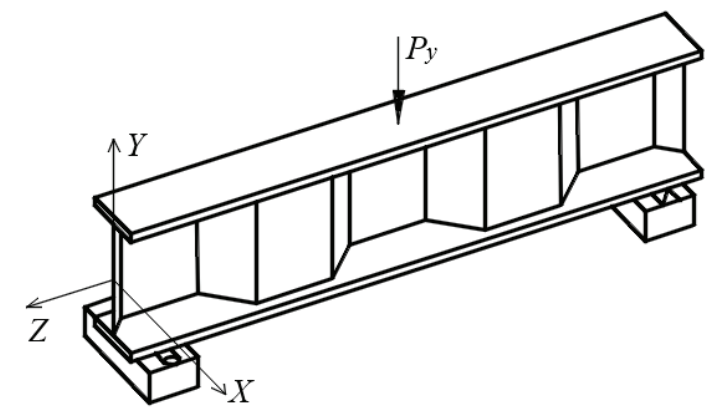

Figure 2. Isometric projection of calculation model with concentrated load at mid-span (in the plane ZOY).

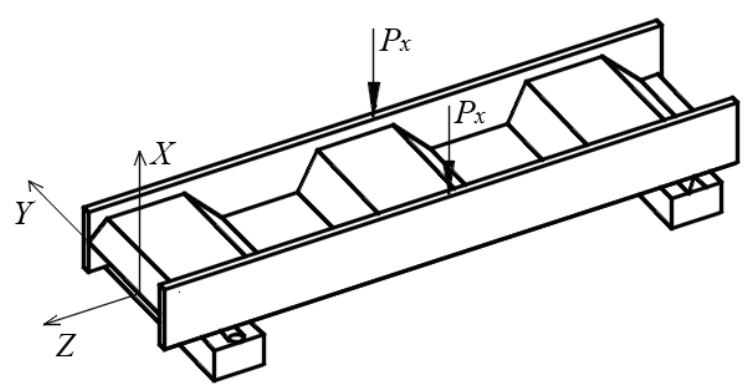

Figure 3. Isometric projection of calculation model with concentrated load at mid-span (in the plane ZOX).

$$
\left.I_{x}=\frac{P_{y} \cdot L^{3}}{48 \cdot E \cdot\left(f_{\max , y}-\frac{3 \cdot P_{y} \cdot L}{20 \cdot G \cdot A_{\mathrm{f}}}\right.}\right),
$$

b. Moment of inertia $I_{y}$ :

$$
I_{y}=\frac{P_{x} \cdot L^{3}}{48 \cdot E \cdot\left(f_{\max , x}-\frac{3 \cdot P_{x} \cdot L}{20 \cdot G \cdot A_{\mathrm{f}}}\right)} .
$$

where, $P_{x}$ and $P_{y}$ are applied loads, $f_{\max , x}$ and $f_{\max , y}$ are maximum deflections along axis $X$ and $Y$.

To determine the reduced area, which is a geometrical parameter under axial impact, the beam is loaded with an axial compressive force $P_{z}$ (Figure 4).

Formula for determining axial deformation: 


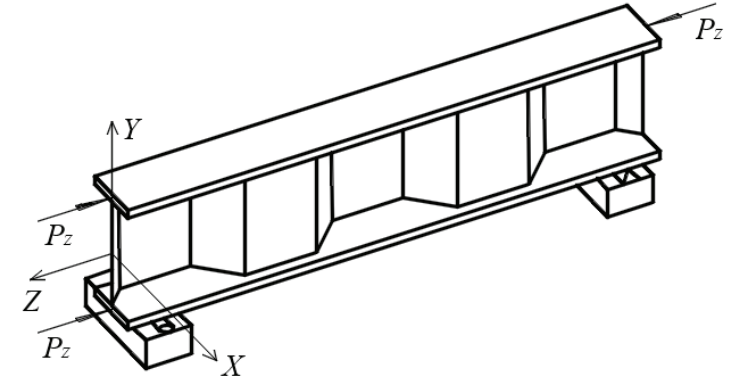

Figure 4. Isometric projection of calculation model with concentrated load along axis $Z$ (in the plane ZOY).

$$
\Delta=\frac{P_{z} \cdot L}{E \cdot A}
$$

where, $\Delta$ is amount of $\mathrm{Z}$-axis displacement. From here, reduced area is determined by the expression:

$$
A=\frac{P_{z} \cdot L}{E \cdot \Delta}
$$

2.2. Selection of cross-sectional dimensions of beams with corrugated web.

For the study were selected five models of Ibeams with trapezoidal webs (BTW1- BTW5). The parameters of the sections of beams were taken in the range of the external height $\mathrm{H}$ from 200 to $600 \mathrm{~mm}$ with a step of $100 \mathrm{~mm}$ (Table 1), which corresponds to assortments of welded I-beams with flat wall.

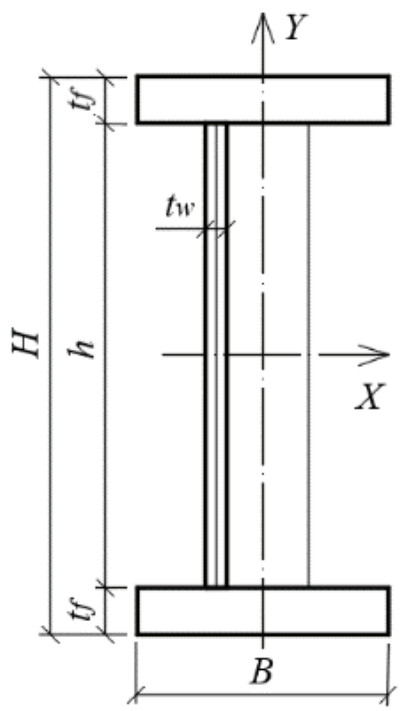

Figure 5. Cross section of models BTW.
Table 1. Parameters of cross section of models BTW.

\begin{tabular}{|c|c|c|c|c|c|}
\hline $\begin{array}{c}\text { Accepted } \\
\text { models }\end{array}$ & $\begin{array}{c}H, \\
\mathrm{~mm}\end{array}$ & $\begin{array}{c}h, \\
\mathrm{~mm}\end{array}$ & $\begin{array}{c}B, \\
\mathrm{~mm}\end{array}$ & $\begin{array}{c}t_{f}, \\
\mathrm{~mm}\end{array}$ & $\begin{array}{c}t_{w}, \\
\mathrm{~mm}\end{array}$ \\
\hline BTW1 & 200 & 184 & 100 & 8 & 2 \\
\hline BTW2 & 300 & 282 & 150 & 9 & 3 \\
\hline BTW3 & 400 & 374 & 200 & 13 & 3 \\
\hline BTW4 & 500 & 468 & 200 & 16 & 4 \\
\hline BTW5 & 600 & 564 & 200 & 18 & 4 \\
\hline
\end{tabular}

\subsection{Selection of trapezoidal webs dimensions for calculation models.}

Studies of various trapezoidal profiles were performed in $[17,18]$. The results of these researches have shown that the most rational in terms of bearing capacity is a beam with a corrugation angle $\varphi=45 \%$. Optimal sizes of parameters $a, b$ and $d$ were determined on basis of comparative automated calculations. The corrugation parameters corresponding to the accepted models are given in table 2 and in Figure 6.
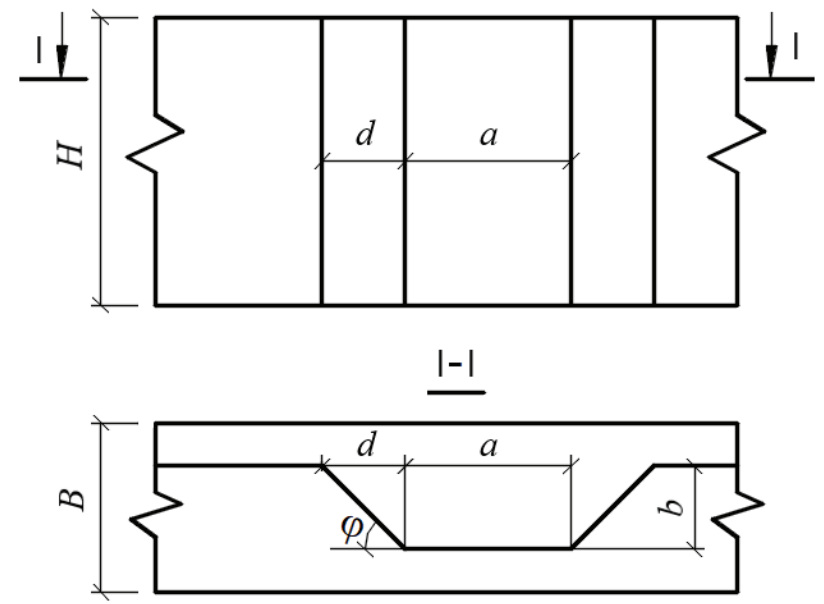

Figure 6. Trapezoidal web dimensions.

Table 2. Parameters of corrugated web beams.

\begin{tabular}{|c|c|c|c|c|}
\hline Models & $b, \mathrm{~mm}$ & $a, \mathrm{~mm}$ & $d, \mathrm{~mm}$ & $\varphi$, \\
\hline BTW1 & 50 & 180 & 50 & $45^{\circ}$ \\
\hline BTW2 & 76 & 150 & 76 & $45^{\circ}$ \\
\hline BTW3 & 100 & 200 & 100 & $45^{\circ}$ \\
\hline BTW4 & 80 & 200 & 80 & $45^{\circ}$ \\
\hline BTW5 & 100 & 300 & 100 & $45^{\circ}$ \\
\hline
\end{tabular}


To the Question of the Determination of Geometric Characteristics of the Section of Corrugated Beams with Trapezoidal Webs Based on the Simulation Results

2.4. Numerical determination of displacement value based on shell finite element model.

The study consisted in calculation of beams based on shell finite element model. Preliminary verification of this model was performed using a flat wall I-beam as an example and subsequent comparison of results with theoretical values of deflections taking into account the shear deformations. Results obtained by numerical analysis in software package "ANSYS", correlated with the analytical calculation with a maximum error of $0.93 \%$, which is within the limits of permissible (taking into account the fact that errors adopted in the construction design should not exceed $3 \%$ ).
Next, the calculation was carried out corrugated beams BTW1-5 to determine:

a) maximum deflections in a beam loaded with concentrated forces in two planes (Figure 2, Figure 3);

b) axial deformation of the beam under axial impact (Figure 4).

The calculation was performed in software package "ANSYS 14.5", where shell finite elements SHELL181 were used. Generation of a grid of quadrangular type was made automatically. The size of finite elements was within 47 $\mathrm{mm}$ on long side. Near the junction of webs and flanges, the mesh dimensions were reduced to 7 $\mathrm{mm}$.

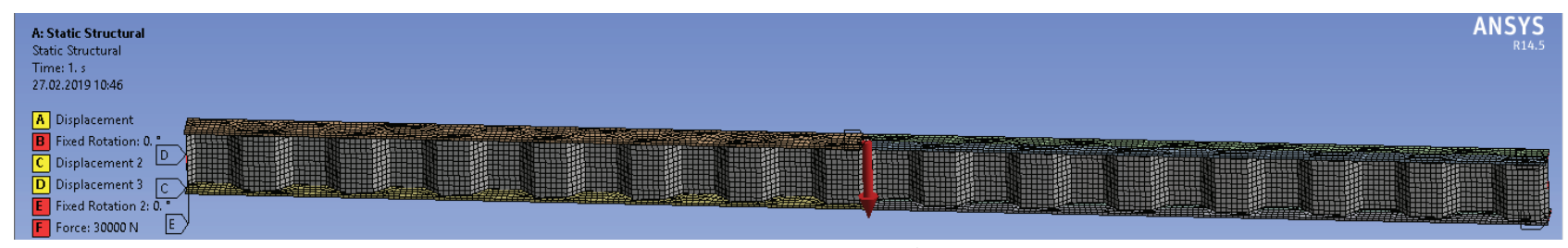

Figure 7. Finite element model of a beam.

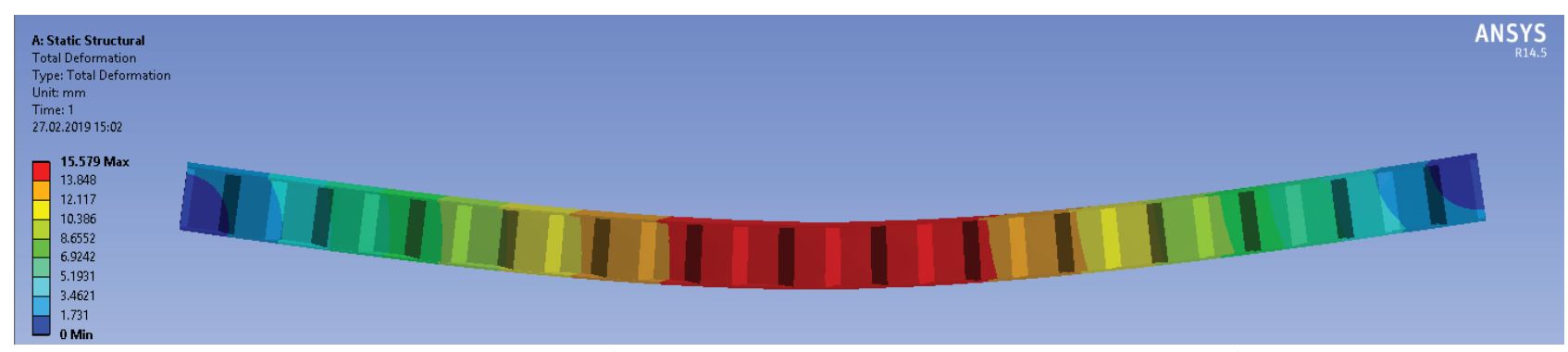

Figure 8. Deformed scheme in YZ plane for the BTW1 model.

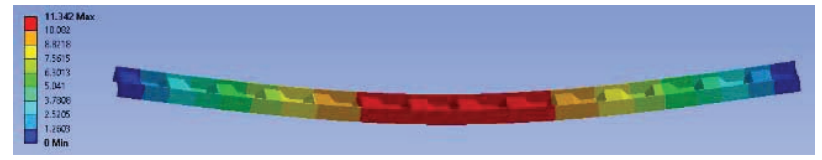

a)

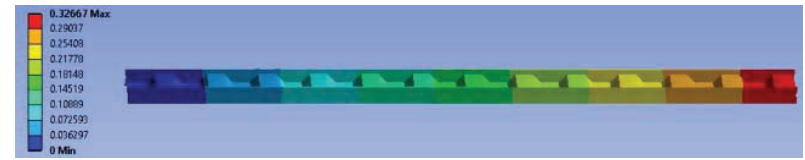

b)

Figure 9. Deformed scheme for the BTW1 model: a) in XZ plane;

b) deformed circuit for axial compression.

The maximum axial displacements and deflections obtained in the calculation are shown in Table 3.
Table 3. Results of calculation.

\begin{tabular}{|c|c|c|c|}
\hline Models & $\begin{array}{c}f_{\max , y}, \\
\mathrm{~mm}\end{array}$ & $\begin{array}{c}f_{\max , x}, \\
\mathrm{~mm}\end{array}$ & $\begin{array}{c}\Delta, \\
\mathrm{mm}\end{array}$ \\
\hline BTW1 & 15.6 & 11.34 & 0.326 \\
\hline BTW2 & 11.1 & 12.2 & 0.25 \\
\hline BTW3 & 10.45 & 11.2 & 0.247 \\
\hline BTW4 & 19.1 & 33.7 & 0.34 \\
\hline BTW5 & 17.45 & 43.7 & 0.38 \\
\hline
\end{tabular}


2.5. Calculations of geometric characteristics. Using obtained maximum deflections ( $f_{\max , y}$, $f_{\max , x}$ ) using the formula (4), moments of inertia about the axes of cross section $X$ and $Y$ were determined for each model of corrugated beams. Reduced area is determined by formula (9). In calculations were used material characteristics

$$
E=200 \mathrm{kN} / \mathrm{mm}^{2}, G=76,9 \mathrm{kN} / \mathrm{mm}^{2} .
$$

Determination of moments of resistance and radius of gyration, perform on the basis of wellknown analytical formulas for strength of materials [19].

$$
\begin{aligned}
& W_{x}=\frac{I_{x}}{H / 2}, \\
& i_{x}=\sqrt{\frac{I_{x}}{A}} .
\end{aligned}
$$

$W_{y}, i_{y}$ - were determined similarly by formulas (10), (11). Static moment of the half-section area relative to the $\mathrm{X}$ - axis was calculated by following formula:

$$
S_{x}^{1 / 2}=\left(\frac{H}{2}-t_{\mathrm{f}}\right) \cdot t_{w} \cdot \frac{1}{2} \cdot\left(\frac{H}{2}-t_{\mathrm{f}}\right)+B \cdot t_{\mathrm{f}} \cdot\left(\frac{H}{2}-\frac{t_{\mathrm{f}}}{2}\right) .
$$

\section{RESULTING TABLE OF GEOMETRIC CHARACTERISTICS OF SECTIONS OF BEAMS WITH CORRUGATED WEB}

According to research results, was compiled a table of parameters and geometrical characteristics of welded I-beam with a corrugated web (similar to tabulated values standard I-beams).

The resulting table can be used to solve the problem of the finite-element analysis of flat frames according to rod diagram, which greatly simplifies the calculation compared to calculation using shell model.

Table 4. Geometric parameters of steel I-beams profiles with corrugated web.

\begin{tabular}{|c|c|c|c|c|c|c|c|c|c|}
\hline \multirow{2}{*}{ Models } & \multicolumn{4}{|c|}{ Cross-section specifications, cm } & \multicolumn{4}{c|}{ Corrugation specification, cm } \\
\cline { 2 - 11 } & $H$ & $B$ & $t_{f}$ & $t_{w}$ & $h$ & $b$ & $a$ & $d$ & $\varphi$ \\
\hline 1 & 2 & 3 & 4 & 5 & 6 & 7 & 8 & 9 & 10 \\
\hline BTW1 & 20.0 & 10.0 & 0.8 & 0.2 & 18.4 & 5.0 & 10.0 & 5.0 & $45^{\circ}$ \\
\hline BTW2 & 30.0 & 15.0 & 0.9 & 0.3 & 28.2 & 7.6 & 15.0 & 7.6 & $45^{\circ}$ \\
\hline BTW3 & 40.0 & 20.0 & 1.3 & 0.3 & 37.4 & 10.0 & 20.0 & 10.0 & $45^{\circ}$ \\
\hline BTW4 & 50.0 & 20.0 & 1.6 & 0.4 & 46.8 & 8.0 & 20.0 & 8.0 & $45^{\circ}$ \\
\hline BTW5 & 60.0 & 20.0 & 1.8 & 0.4 & 56.4 & 10.0 & 30.0 & 10.0 & $45^{\circ}$ \\
\hline
\end{tabular}

Table 5. Geometric parameters of steel I-beams profiles with corrugated web.

\begin{tabular}{|c|c|c|c|c|c|c|c|c|}
\hline $\begin{array}{c}\text { Area, } \\
\mathrm{cm}^{2}\end{array}$ & $\begin{array}{c}\text { Mass } \\
\text { per } \\
1 \mathrm{~m}, \mathrm{~kg}\end{array}$ & $\begin{array}{c}I_{x}, \\
\mathrm{~cm}^{4}\end{array}$ & $\begin{array}{c}W_{x}, \\
\mathrm{~cm}^{3}\end{array}$ & $\begin{array}{c}i_{x}, \\
\mathrm{~cm}\end{array}$ & $\begin{array}{c}I_{y}, \\
\mathrm{~cm}^{4}\end{array}$ & $\begin{array}{c}W_{y}, \\
\mathrm{~cm}^{3}\end{array}$ & $\begin{array}{c}i_{y}, \\
\mathrm{~cm}\end{array}$ & $\begin{array}{c}S_{x}^{1 / 2}, \\
\mathrm{~cm}^{3}\end{array}$ \\
\hline 11 & 12 & 13 & 14 & 15 & 16 & 17 & 18 & 19 \\
\hline 19.68 & 16.13 & 1484.2 & 148.42 & 8.68 & 136 & 27.2 & 2.63 & 85.3 \\
\hline 35.46 & 29.24 & 5712 & 380.8 & 12.7 & 520 & 69.3 & 3.83 & 226.3 \\
\hline 63.22 & 51.54 & 18922 & 946.1 & 17.3 & 1765.5 & 176.6 & 5.3 & 555.6 \\
\hline 82.72 & 67.8 & 38312 & 1532.48 & 21.52 & 2172 & 217.2 & 5.13 & 1212.45 \\
\hline 94.56 & 77.3 & 61893 & 2063.1 & 25.6 & 2472 & 247.2 & 5.11 & 1763.4 \\
\hline
\end{tabular}


To the Question of the Determination of Geometric Characteristics of the Section of Corrugated Beams with Trapezoidal Webs Based on the Simulation Results

\section{CALCULATION OF A FLAT FRAME WITH CORRUGATED ELEMENTS}

Using the geometrical characteristics of corrugated beams, it was possible to perform calculations of flat frames according to rod diagram. Let us give an example of the calculation of a flat frame with a horizontal corrugated element, made in software «LIRA_SAPR» using a flat rod diagram.

Example. Consider the frame shown in Fig. 11. For this frame requires: a) build the internal forces diagrams(the axial force $N$, the shear $Q$, and the bending moment $M$ ); b) determine the maximum normal and stress shearing in the rod of the column and beam.

Initial data: $L=12 \mathrm{~m} ; q=14 \mathrm{kN} / \mathrm{m} ; E=200$ $\mathrm{kN} / \mathrm{mm}^{2}$.

The cross section of the beam - corrugated beam with plate trapezoidal web (BTW5), columns the standart I-beam with flat wall (50ШC2). The geometric characteristics of the cross section for the beam are selected from Table 5 and 6 .
Calculated geometric characteristics of the cross section of elements: elements 1 and 2: $I=7,22$ $\cdot 10^{-4} \mathrm{~m}^{4} ; W=29,5 \cdot 10^{-4} \mathrm{~m}^{3} ; A=176,25 \cdot 10^{-4} \mathrm{~m}^{2}$; $S_{x}{ }^{1 / 2}=16,65 \cdot 10^{-4} \mathrm{~m}^{3}$; the element $3: I=6,2 \cdot 10^{-4}$ $\mathrm{m}^{4} ; \quad W=2,63 \cdot 10^{-4} \mathrm{~m}^{3} ; \quad A=94,56 \cdot 10^{-4} \mathrm{~m}^{2}$; $S_{x}^{1 / 2}=17,63 \cdot 10^{-4} \mathrm{~m}^{3}$.

Assign stiffnesses rod elements: for elements 1 and 2: $E I=144400 \mathrm{kN} \cdot \mathrm{m}^{2} ; E A=3525000 \mathrm{kN}$; for element 3: $E I=124000 \mathrm{kN} \cdot \mathrm{m}^{2}$;

$E A=1891200 \mathrm{kN}$.

\section{Calculation results}

a. The internal forces diagrams, received in software «LIRA-SAPR» shown in Fig. 11, Fig. 12.

b. The calculation of normal stresses in rods of column and beam of frame:

$$
\sigma_{i}, \frac{\max }{\min }=\frac{N_{i}}{A_{i}} \pm \frac{M_{i}}{W_{i}}
$$

where, $i=1,2,3$ - numbers of rod.

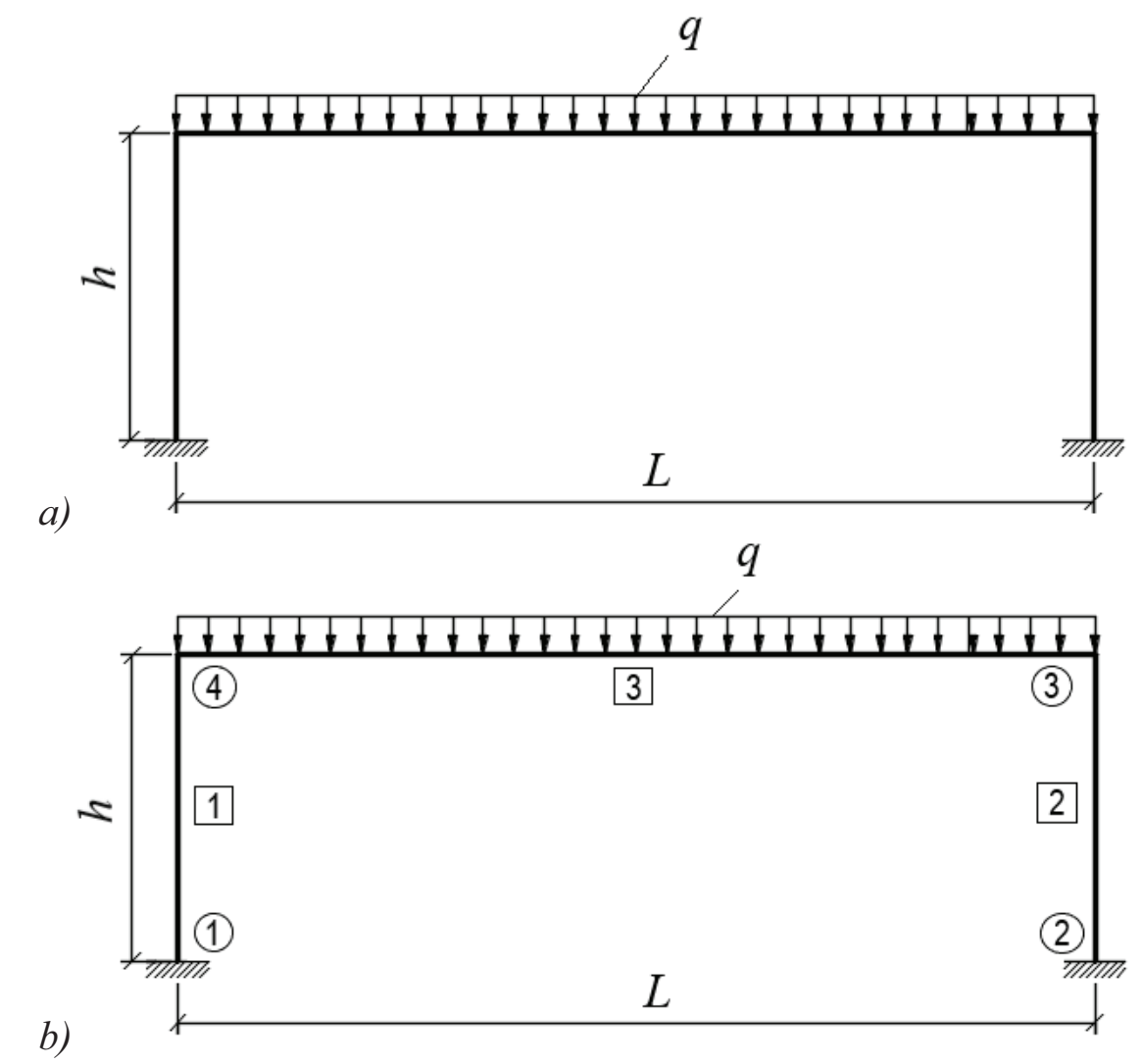

Figure 10. The rod model of a flat steel frame: a) frame geometry; b) calculation scheme. 
Diagram My

Units of measurement - $\mathrm{kN}^{*} \mathrm{~m}$

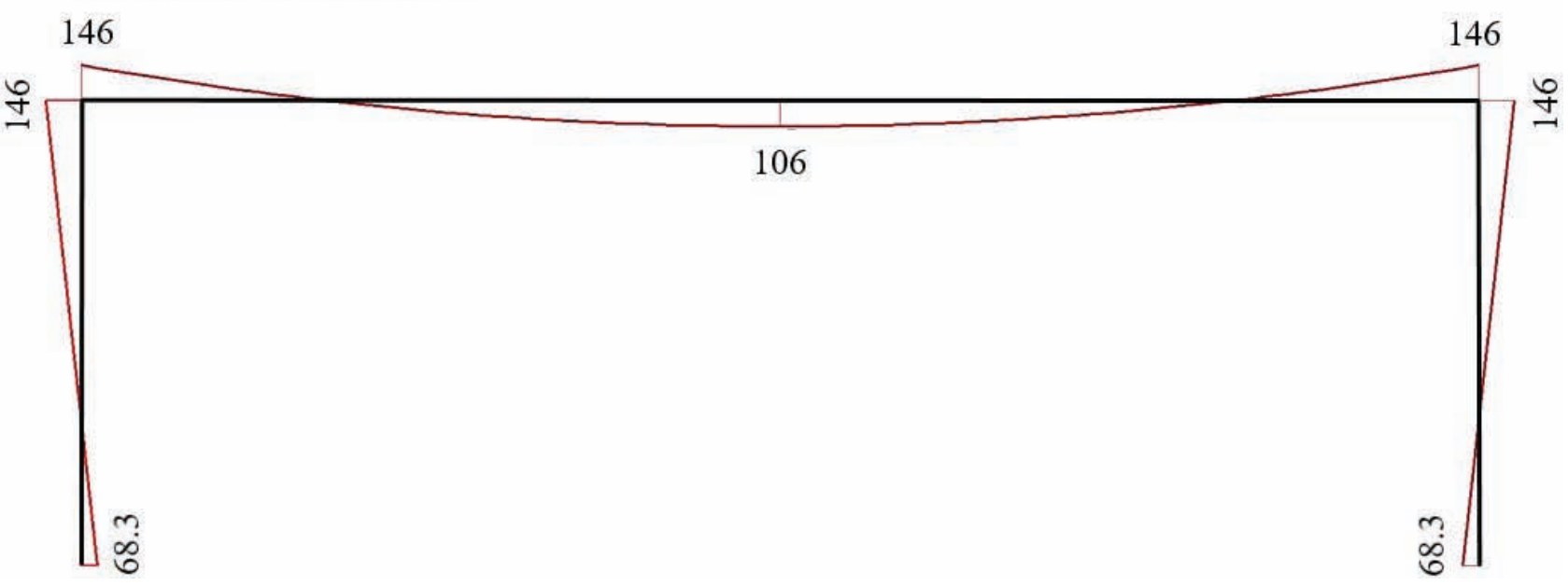

Figure 11. The calculation in Software "LIRA-SAPR": the diagram of bending moment My.

\section{Diagram Q \\ Units of measurement - $\mathrm{kN*} \mathrm{m}$}

84

a)

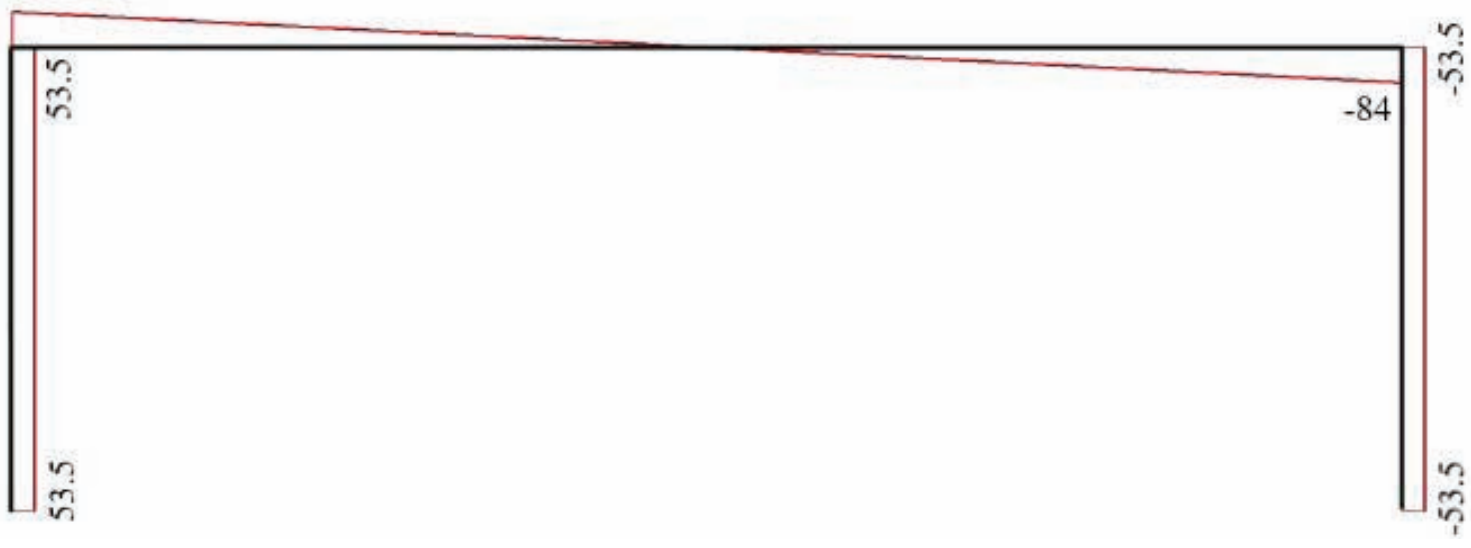

Diagram N

Units of measurement - $\mathrm{kN}$

b)

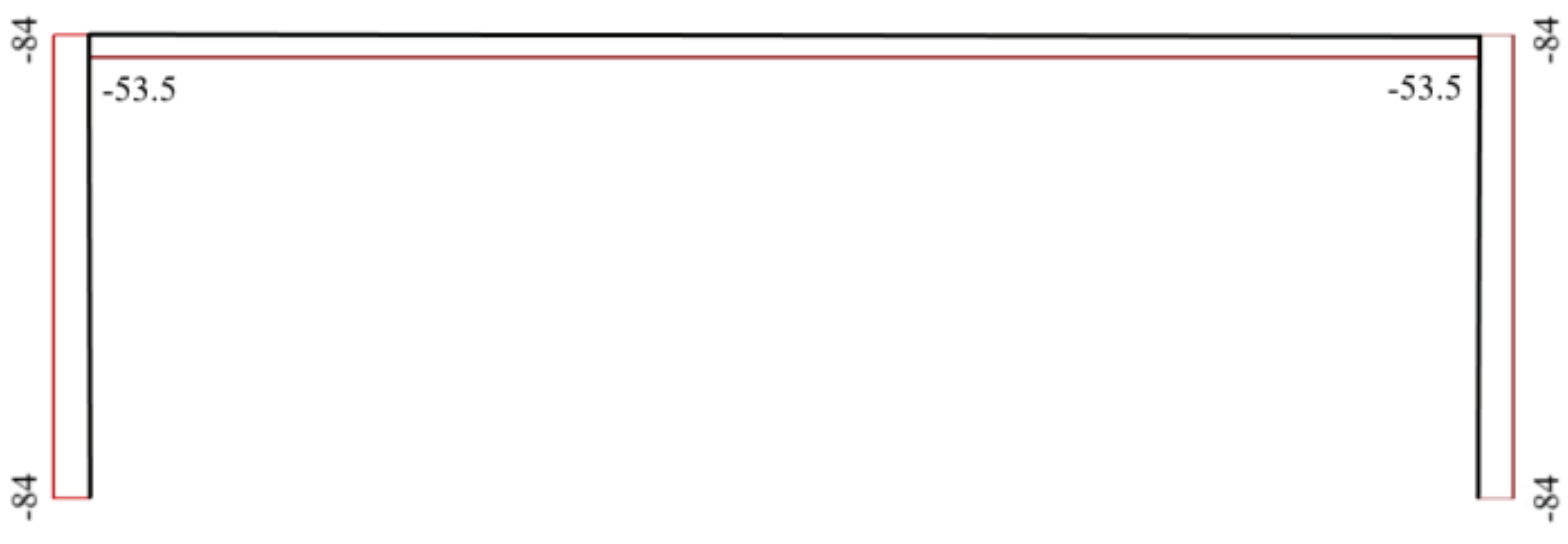

Figure 12. The calculation in Software "LIRA-SAPR": a) the diagram of shear $Q$;

$b)$ the diagram of axial force $N$. 
To the Question of the Determination of Geometric Characteristics of the Section of Corrugated Beams with Trapezoidal Webs Based on the Simulation Results

Table 6. Results of calculations.

\begin{tabular}{|c|c|c|}
\hline Elements & $\sigma_{i, \max }, \mathrm{MPa}$ & $\sigma_{i, \min }, \mathrm{MPa}$ \\
\hline 1 & 44,7 & $-54,4$ \\
\hline 2 & 44,7 & $-54,4$ \\
\hline 3 & 65,2 & $-76,43$ \\
\hline
\end{tabular}

c. The calculation of stress shearing in rods of column and beam of frame:

$$
\tau_{i}=\frac{Q \cdot S_{x}^{1 / 2}}{I_{x} \cdot t_{w}}
$$

Table 7. Results of calculations.

\begin{tabular}{|c|c|}
\hline Elements & $\tau_{i}, \mathrm{MPa}$ \\
\hline 1 & 8,23 \\
\hline 2 & $-8,23$ \\
\hline 3 & 59,73 \\
\hline
\end{tabular}

\section{CONCLUSION}

1. The developed method makes it possible to determine the values of geometric characteristics for corrugated web I-beams with various corrugation configurations.

2. The use of the obtained geometric characteristics makes it possible to carry out the calculation of flat frames with corrugated elements according to the rod scheme.

3. Further research direction involves the generalization of the above method to solving problems of static calculation of spatial rod structures with corrugated elements.

\section{REFERENCES}

1. Dmitrieva T.L., Ulambayar Kh. Ispolizovanie Balok s Gofrostenkoi v Sovremennom Proektirovanii [Use of Corrugated Beams in Modern Design]. // Izvestiya Vuzov. Investitsii. Stroitelstvo. Nedvizhimost, 2015, Vol. 15, No. 4, pp. 132-138 (in Russian).

2. Limaye A.A., Alandkar P.M. Strength of Welded Plate Girder with Corrugated Web
Olate. // International Journal of Engineering Research and Applications, 2013, Vol. 3, Issue 05, pp. 1925-1930.

3. Bryantsev A.A., Absimetov V.E., Lalin V.V. Effiktivnosti Primeneniya Dvutavrov s Gofrirovanniimi Stenkami v Proizvodstvenniikh Zdaniyakh [Effective Application of I-beams With Corrugated Webs in the Industrial Building]. // Construction of Unique Buildings and Structures, 2017, Vol. 54, No. 3, pp. 93-104 (in Russian).

4. Lukin A.O., Alpatov V.Yu., Chernyshev D.D. Sovershensvovanie Konstruktivnogo Resheniya Balki s Gofrirovannoi Stenkoi [Improving Constructive Solution of Beam With Corrugated Wall]. // Vestnik SGASU. Town Planning and Architecture, 2016, Vol. 23, No. 2, pp. 4-8 (in Russian).

5. Akshay Bankar, Pallavi Pasnur. Experimental Stress Analysis of Trapezoidal Corrugated Steel Web Beam - A Review. // Imperial journal of Interdisciplinary Research, 2017, Vol. 3, Issue 06, pp. 621-624.

6. Jayaraman S., Suresh babu S. Experimental Investigation on Flexural Behavior of Cold Formed Corrugated Steel Section. // International Journal for Scientific Research and Development, 2017, Vol. 5, Issue 02 , pp. 1670-1675.

7. Bondarenko O.S., Kikot A.A. Analiz Balok s Gofrirovannoi Stenkoi [Corrugated Beam Analysis]. // Polzunovski Almanakh, 2016, No. 3, pp. 38-41 (in Russian).

8. Kudryavtsev S.V. Raschet Dvutavrovoi Balki s Gofrirovannoi Stenkoi na Izgib v Svoei Ploskosti pod Deistviem Staticheskikh Nagruzok. Rashet Metodom Konechniikh Elementov [Calculation of an I-Beam With a Corrugated Web for Bending in its Plane Under the Action of Static Loads. Calculation Finite Element Method]. Ekaterinburg, GOU BPO UPI, 2007, 11 pages (in Russian).

9. Basher M.A., Shanmugam N.E., Khalim A.R. Horizontally Curved Composite Plate Girders With Trapezoidally Corrugated 
Webs. // International Journal of Constructional Steel Research, 2011, Vol. 67, Issue 06, pp. 947-956.

10. Wang Z.Y., Wang Q.Y., Jiang R.J. Finite Element Based Fatigue Assessment of Corrugated Steel Web Beams in Highway Bridges. // International Journal of Civil Engineering, 2015, Vol. 13, Issue 04, pp. 419-431.

11. Revathi N., Satheshkumar G.K., Arunkumar Dr.G. Numerical Investigation on Flexural Behaviour of Cold Formed Steel I - Section With Triangular Corrugated Web. // International Journal of Research and Innovation in Engineering Technology, 2016, Vol. 02, Issue 12, pp. 48-53.

12. Siddharth R.P., Magdum M.M. Comparative Study of Innovative Corrugated Hollow Columns and Conventional Column. // Technical Research Organization India, 2017, Vol. 04, Issue 07, pp. 30-37.

13. Arunkumar G., Sampathkumar P., Sukumar S. Investigation on Cold Formed Steel Lipped I-Beam With Trapezoidal Corrugation in Web by Varying Depth. // International Journal of Innovative Research and Development, 2013, Vol. 02, Issue 05, pp. 938-949.

14. Denan F., Osman M.H., Saad S. The Study of Lateral Torsional Buckling Behavior of Beam with Trapezoid Web Steel Section by Experimental and Finite Element Analysis. // International Journal of Research and Reviews in Applied Sciences, 2010, Vol. 02, Issue 03, pp. 232240.

15. Maksimov Yu.S., Ostrikov G.M. Sortament Svarniikh Dvutavroviikh Profilei Obiichnogo Tipa i s Gofrirovannimi Stenkami, Sootvetstvuiushie po Prochnostniim Kharakteristikam Prokatniim [Mix of Fabricated I-Beam Sections of Regular Type and With Corrugated Walls Meeting Strength Properties of Rolling Sections]. RDS RK
5.04-24-2006, Astana: Kaz Steel Project, 2007, 22 pages (in Russian).

16. Rekomendatsii po Proektirovaniiu: Balki Dvutavroviie Gofrirovanniie Oblegchenniie [Design Recommendations: Lightweight IBeams Corrugated] (Sin beams TU U B.2.6-28.1-30653953-007:2007) Kh., et. project, 2013, 110 pages (in Russian).

17. Prabha V.C., Shalini A., Saravanaganesh S., Selvakumar K. Study on Behaviour of Cold Formed Built-Up I-Section With Trapezoidal Corrugation in Web by Varying the Aspect Ratio and Angle of Corrugation. // International Journal of Chemical Sciences, 2015, Vol. 13, Issue 04, pp. 1935-1946.

18. Divahar R., Joanna P.S. Lateral Buckling of Cold Formed Steel Beam With Trapezoidal Corrugated Web. // International Journal of Civil Engineering and Technology, 2014, Vol. 05, Issue 03, pp. 217-225.

19. Alexandrov A.V., Potapov V.D., Derzhavin B.P. Soprotivlenie Materialov [Mechanics of Materials with Elements of Theory of Linear Elasticity]. Moscow, Visshaya shkola, 2003, 560 pages (in Russian).

\section{СПИСОК ЛИТЕРАТУРЫ}

1. Дмитриева Т.Л., Уламбаяр Х. Использование балок с гофростенкой в современном проектировании. // Известия вузов. Инвестиции. Строительство. Недвижимость, 2015, том 15, №04, с. 132138.

2. Limaye A.A., Alandkar P.M. Strength of Welded Plate Girder with Corrugated Web Olate. // International Journal of Engineering Research and Applications, 2013, Vol. 3, Issue 05, pp. 1925-1930.

3. Брянцев А.А., Абсиметов В.Э., Лалин В.В. Эффективность применения двутавров с гофрированными стенками в производственных зданиях. // Cmpou- 
To the Question of the Determination of Geometric Characteristics of the Section of Corrugated Beams with Trapezoidal Webs Based on the Simulation Results

тельство уникальных зданий и сооружений, 2017, том 54, №03, с. 93-104.

4. Лукин А.О., Алпатов В.Ю., Чернышев Д.Д. Совершенствование конструктивного решения балки с гофрированной стенкой. // Вестник СГАСУ. Градостроительство и архитектура, 2016, том 23, №02, c. 4-8.

5. Akshay Bankar, Pallavi Pasnur. Experimental Stress Analysis of Trapezoidal Corrugated Steel Web Beam - A Review. // Imperial journal of Interdisciplinary Research, 2017, Vol. 3, Issue 06, pp. 621-624.

6. Jayaraman S., Suresh babu S. Experimental Investigation on Flexural Behavior of Cold Formed Corrugated Steel Section. // International Journal for Scientific Research and Development, 2017, Vol. 5, Issue 02 , pp. 1670-1675.

7. Бондаренко О.С., Кикоть А.А. Анализ балок с гофрированной стенкой. // Ползуновский альманах, 2016, №03, с. 38-41.

8. Кудрявцев С.В. Расчет двутавровой балки с гофрированной стенкой на изгиб в своей плоскости под действием статических нагрузок. Расчет методом конечных элементов. - Екатеринбург: ГОУ ВПО УПИ. 2007. - 11 c.

9. Basher M.A., Shanmugam N.E., Khalim A.R. Horizontally Curved Composite Plate Girders With Trapezoidally Corrugated Webs. // International Journal of Constructional Steel Research, 2011, Vol. 67, Issue 06, pp. 947-956.

10. Wang Z.Y., Wang Q.Y., Jiang R.J. Finite Element Based Fatigue Assessment of Corrugated Steel Web Beams in Highway Bridges. // International Journal of Civil Engineering, 2015, Vol. 13, Issue 04, pp. 419-431.

11. Revathi N., Satheshkumar G.K., Arunkumar Dr.G. Numerical Investigation on Flexural Behaviour of Cold Formed Steel I - Section With Triangular Corrugated Web. // International Journal of Research and Innovation in
Engineering Technology, 2016, Vol. 02, Issue 12, pp. 48-53.

12. Siddharth R.P., Magdum M.M. Comparative Study of Innovative Corrugated Hollow Columns and Conventional Column. // Technical Research Organization India, 2017, Vol. 04, Issue 07, pp. 30-37.

13. Arunkumar G., Sampathkumar P., Sukumar S. Investigation on Cold Formed Steel Lipped I-Beam With Trapezoidal Corrugation in Web by Varying Depth. // International Journal of Innovative Research and Development, 2013, Vol. 02, Issue 05, pp. 938-949.

14. Denan F., Osman M.H., Saad S. The Study of Lateral Torsional Buckling Behavior of Beam with Trapezoid Web Steel Section by Experimental and Finite Element Analysis. // International Journal of Research and Reviews in Applied Sciences, 2010, Vol. 02, Issue 03, pp. 232240.

15. Максимов Ю.С., Остриков Г.М. Сортамент сварных двутавровых профилей обычного типа и с гофрированными стенками, соответствующие по прочностным характеристикам прокатным РДС РК 5.04-24-2006. - Астана: Каз. сталь проект, 2007. - 22 с.

16. Рекомендации по проектированию: Балки двутавровые гофрированные облегченные (Гофробалки ТУ У В.2.6-28.130653953-007:2007). Х.: Мет.проект, 2013. - $110 \mathrm{c}$.

17. Prabha V.C., Shalini A., Saravanaganesh S., Selvakumar K. Study on Behaviour of Cold Formed Built-Up I-Section With Trapezoidal Corrugation in Web by Varying the Aspect Ratio and Angle of Corrugation. // International Journal of Chemical Sciences, 2015, Vol. 13, Issue 04, pp. 1935-1946.

18. Divahar R., Joanna P.S. Lateral Buckling of Cold Formed Steel Beam With Trapezoidal Corrugated Web. // International Journal of Civil Engineering 
and Technology, 2014, Vol. 05, Issue 03, pp. 217-225.

19. Александров А.В., Потапов В.Д., Державин Б.П. Сопротивление материалов. - М.: Высшая школа, 2003. - 560 с.

Tatiana L. Dmitrieva, Dr.Sc., Professor, Department of Theoretical Mechanics and Strength of Materials, Irkutsk National Research Technical University, Lermontov street, 83, Irkutsk, 664074, Russia; phone/fax: + 7(914)9136125;

E-mail:dmitrievat@list.ru.

Khukhuudei Ulambayar, Ph.D. Student, Department of Automated Systems, Irkutsk National Research Technical University, Lermontov street, 83, Irkutsk, 664074, Russia; phone/fax: + 7(914)8746115;

E-mail: Ulambayar_kh@yahoo.com.

Дмитриева Татьяна Львовна, доктор технических наук, профессор, кафедра теоретической механики и сопротивления материалов, Иркутский национальный исследовательский технический университет, 664074, Россия, г. Иркутск, ул. Лермонтова, 83; тел.+7(914)9136125, E-mail: dmitrievat@list.ru.

Хухуудэй Уламбаяр, аспирант, кафедра автоматизированных систем, Иркутский национальный исследовательский технический университет; 664074, Россия, г. Иркутск, ул. Лермонтова, 83, тел. + 7(914)8746115;

E-mail: Ulambayar_kh@yahoo.com. 